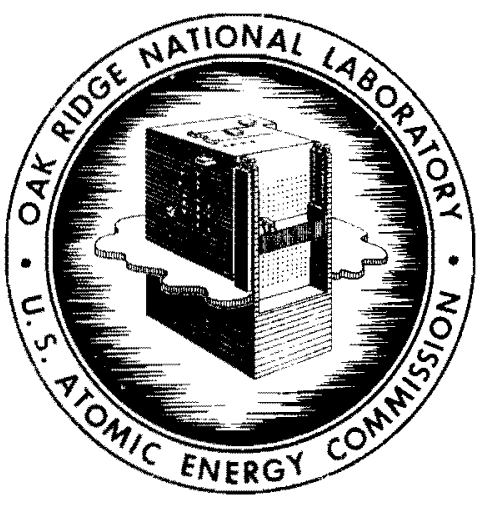

OAK RIDGE NATIONAL LABORATORY

operated by

UNION CARBIDE CORPORATION

for the

U.S. ATOMIC ENERGY COMMISSION

$$
\begin{gathered}
\text { ORNL- TM- } 2 \% \\
206
\end{gathered}
$$

ADMINISTRATION OF ORNL RESEARCH REACTORS

W. R. Costo

This document contains information of a preliminary nature and was prepared primarily for internal use of the Oak Ridge National Laboratory. It is subiect to revision or correction and therefore does not represent a final repart. The information is not to be abstracted, reprinted or otherwise given public dis. semination without the approval of the ORNL patent branch, Legal and infor. motion Control Departrnent. 
This report wos prepared os on account of Government sponsored work. Neither the United Slotes; nor the Commission, nor any person acting on behall of the Commission:

A. Mekes any worronty or representation, expressed or implied, with respect to the occuracy, completeness, or usefulness of the infotmotion contained in this report, of that the use of any information, apparatus, method, or process disclosed in this report may not infringe privately owned rights; or

B. Assumes any liabillties with respect to the use of, or for domages resulting from the use of any informotion, apperofus, methad, or process disclosed in this report.

As used in the above, "person acting on beholf of the Commission" includes any employee or contractor of the Commission, or employee of such controctor, to the extent that such employee or contractor of the Commission, or mployee of such contractor prepares, disseminates, or provides occess to, ony informotion pursuont to his employment or contract with the Commission, or his employment with such contractor. 
ORNL-TM-276

Contract No. W-7405-eng-26

\title{
ADMINISTRATION OF ORNL RESEARCH REACTORS
}

\author{
W. R. Casto \\ Paper presented at Conference on \\ Light-Water-Moderated Research Reactors \\ June 11-14, 1962 \\ Gatlinburg, Tennessee
}

Date issued

by 9 a ma

OAK RIDGE NATIONAL LABORATORY

Oak Ridge, Tennessee operated by UNION CARBIDE CORPORATION

for the

U.S. Atom ic Energy Commission 


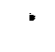




\section{ADMINISTRATION OF ORNL RESEARCH REACTORS}

W. R. Casto

I. INTRODUCTION

The three routinely operated research reactors at the Oak Ridge National Laboratory, namely the Oak Ridge Research Reactor (ORR), the Low Intensity Testing Reactor (IITR), and the Oak Ridge Graphite Reactor (OGR) are under the jurisdiction of the Operations Division. Of the five Departments of this Division, three, Reactor Operations, Development, and Technical Assistance, are directly involved with the operation of these reactors. The organization of the Operations Division is given in Figure 1. 


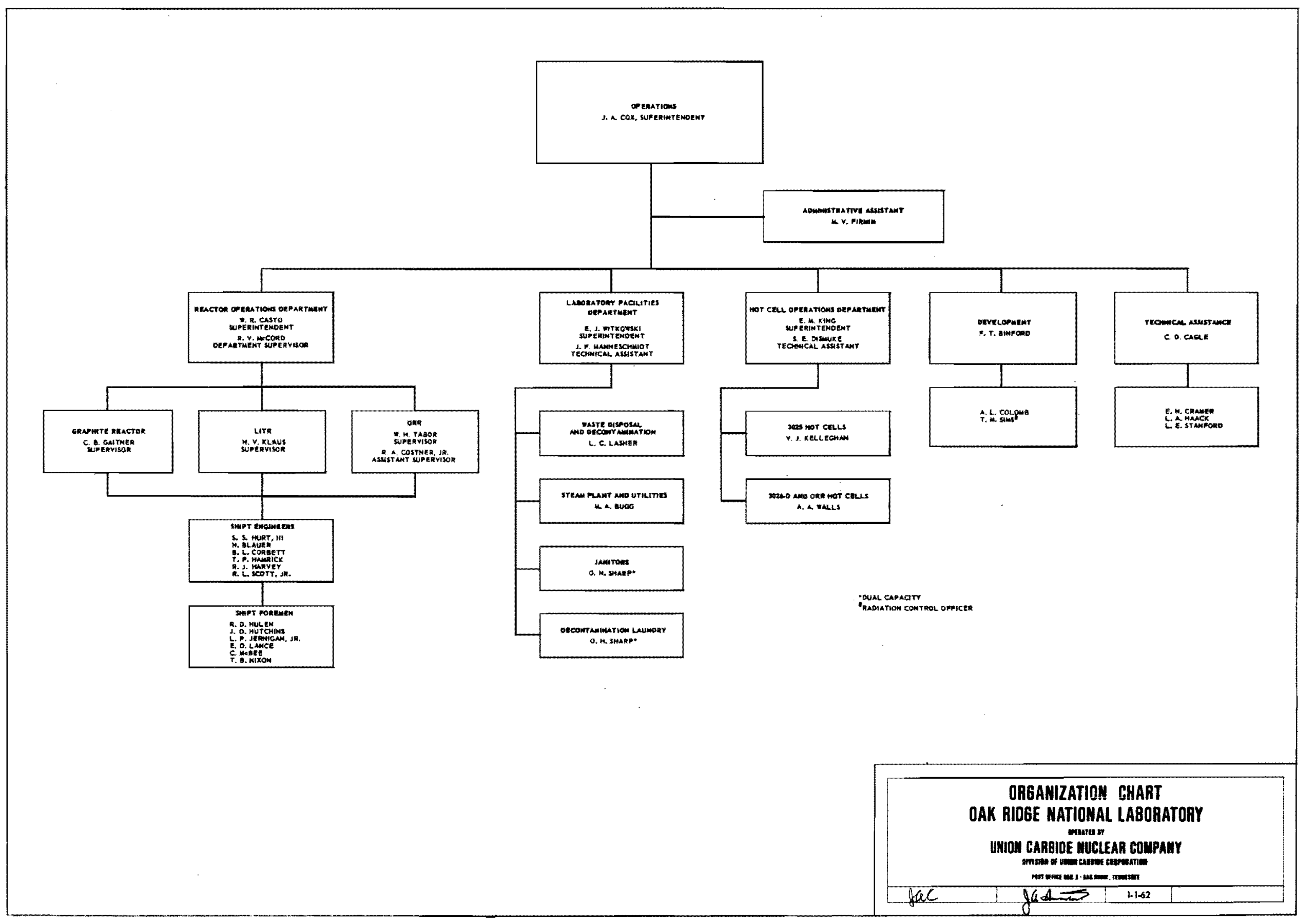

FIGURE 1 


\section{MANPOWER AND ORGANIZATION}

\section{A. Reactor Operations Department}

1. Function

The Reactor Operations Department is responsible fior the direct dayto-day operation of the $O R R$, the $L I I R$, and the OGR. Operating procedures are established with the assistance of the Technical Assistance and Development Departments. Ir addition, various safety committees of management may review operations and make recommendations.

It is the responsibility of the Reactor Operations Department to conduct the operation of the reactors within tre limits outlined in the operating procedures. The Departmert is primarily concerned with production but in a different sense than is the case with a power reactor, where a good record is usually measured in terms of megawatt days per year. With a research reactor the product is the scientific and engineering data compiled by investigators using the reactor, and this is often augmented by occasional reactor shutdown. Safety also plays an important role throughout the operation of the reactors, and the Department mus remein sensible to its responsibility in this respect.

\section{Supervision}

In general there are three levels of skill necessary for the operation of nuclear reactors.

a. The Nuclear Reactor Engineer. " "This category demands a high degree of technical competence and knowledge including the ability to analyze and treat with the various aspects of reactor technology. The nuclear-reactor engineer must have a thorough working knowledge of the physical principles associated with the design and operation of a nuclear 
reactor and its ancillary facilities. His educational background will include an undergraduate degree in engineering or one of the physical sciences plus considerable specialized work at the graduate level in reactor technology. From the ranks of the nuclear reactor engineers are drawn the reactor designers, experiment designers, safeguard specialists, technical support personnel, and often top operations supervision." 3

b. The Operation Engineer.--"The operation engineer is distinguished from the nuclear engineer in that the former is generally charged with the direct responsibility of supervising the implementation of procedures established by the latter. It is not so necessary that the operation engineer have a profound knowledge of the physical principles underlying his operation; however, he must be thoroughly familiar with the machinery under his control and must understand its behavior and, in particular, its limitations. Usually the operation engineer is required to have an undergraduate degree in engineering and some specialized training, often acquired on the job, in reactor engineering."3

c. The Reactor Fechnician.--"The reactor technicians are the individuals who, under the supervision of the reactor engineer or the operating engineer, perform the actual manipulations required to operate the facility. In general, these persons are trained on the job to perform essentially repetitive tasks. They must be emotionally stable, intelligent, and have a reasonable degree of manual dexterity. The educational requirements vary with the particular facility; however, at ORNL a high school diploma is the maximum." 3

All of the supervisors employed in the Reactor Operations Department, with the exception of the foremen, have degrees in one of the physical 
sciences. It has been found that undergraduate degrees with a broad base in the physica]. sciences, such as physics or engineering, seem to offer the best background for reactor operations supervision. A reactor operam tions supervisor needs rot orily technical training but also experience, anả the Reactor Operations Department supervisors above the foremen have an average of five years reactor experience. All the foremen have a high school. education. These men started as reactor operators and were prow moted to the position of foremen. As foremen they have accumulated an average of seven years of reactor experience. Previously, as reactor operators, they had also worked an average of seven jears.

3. Organization

Orgenization of the supervision of the Reactor Operations Department is show in Figure 2. Operation of the ORR is so complex that an Assistant Reactor Supervisor and ar extra foremar are required. The four shift crews that are used to mon the reactor continuousiy, on rotating eight-hour shifts, report to the three reactor supervisors. Each shift is composed of a reactor engineer, a shift foremain, and four reector operam tors. At the ORR the line of authority is through the chief anft wnelneer who is responsible to the assistant reactor supervison and does rejief work for the four shift enginears. The relief foreman is the substitute for the shift foreman and for the reactor superviso's of the IITR and OGR. When not occupied in this manner, he works on special assignments at the three reactors.

4. Reactor Operators

Reactor operators are required to have at least a hich sciooi education or to pass an examination proving high school equivalence. In recent 
years, an I.Q. test and a mechanical-comprehension test have also been given to applicants for the operator job. People of average intelligence make a score of 90 to 100 on the Otis test used at ORNL. The average grade on the Bennett Mechanical-Comprehension test used is 62 .

All operators who have been employed since use of the tests has bee: initiated have achieved an I.Q. score of at least 100 and a mechanical comprehension score of at least 80 . Nen with experience in chemical plants, where they have worked with control and indicating instruments, can easily be trained as reactor operators. ${ }^{4}$ Experience with equipment associated with heat transfer, fluid flow, and mechanical operations is also valuable background for a reactor operator.

A labor union, Atomic Trades and Labor Council, represents nonsupervisory employees in discussions with ORNL management, Union Carbide Nuclear Company •

A labor contract agreed to by the Company and the union, provides that "Supervisory personnel shall not do nonsupervisory work which will deprive employees of jobs regularly performed by them. This does not prevent such supervisory personnel from performing necessary functions of instruction or assistance to employees, or from operating equipment or processes in emergencies or for experimental purposes."

In general, reactor operators discharge many tasks requiring manual labor, in addition to operating reactor controls, such as starting pumps, opening and closing valves, handling fuel, obtaining water samples, recording data, executing housekeeping duties, etc. All the aforementioned jobs are performed under the guidance and direction of the supervisors. 
B. Technical Departments

1. Function

In addition to the Reactor Operations Department, the Technical Assistance Department and the Development Department devote their time almost exclusively to reactor operations. In general, the Technical Department gives aid on technical problems of operations and reviews proposed reactor experiments from a safety viewpoint. The Development Department deals with technical problems that do not immediately affect the reactors. Typical projects are as follows:

1. Preparation of reactor experiments for safety review,

2. Review of reactor experiments for safety, ${ }^{1}$

3. Development of a hydraulic test facility for ORR core pieces, 4. Development of procedures for annealing the Graphite Reactor, 5. Training, 4

6. Development of fuel-loading cycles for the $\mathrm{ORR},{ }^{6}$

7. Development of a boiling detection device for water-cooled reactors, 7 and

8. Development of specifications for reactor fuel.

C. General Manpower

Fortymeight people in the Operations Division are engaged in the operation of the three research reactors. The distribution is broken down in Table 2. 


$$
=
$$

Table 2. Nampwer for Operation of ORUL Research Reactors

\begin{tabular}{|c|c|c|c|c|}
\hline Departinem & $\begin{array}{l}\text { Technical stafe } \\
\text { and Supervision }\end{array}$ & woremen & $\begin{array}{l}\text { Reactor } \\
\text { operators }\end{array}$ & Clerical \\
\hline Reactor Operations & 9 & 7 & 22 & 1 \\
\hline Technical Assistance & it. & & & $I$ \\
\hline Development & 4 & & & \\
\hline Total & .77 & 7 & 22 & 2 \\
\hline
\end{tabular}

Because many of these people hare responsibilities at all three reactors, an exact delineation of manpower required for each reactor is not possible. An estimate is shom in Tiable 3.

Table 3. Estimated Ianpower pex Reactor

\begin{tabular}{lccccc}
\hline Reactor & Reactor Operators & Clerical & Supervisors & Techical & Motal \\
\hline ORR & 14 & 2 & 9 & 6 & 31 \\
IITR & 3 & 3 & 1 & 1 & 10 \\
OGR & 5 & 4 & 1 & 1 \\
\hline
\end{tabular}

Obviously, it would not be possible to operate a single isolated. reactor similar to tine IIIR continuoxsly with only thwee reactor operators and three supervisors. However, tris is done at the LITR by sharing per. sonnel with the other reactors. The 31 people required for the ORR operation is similarly low. Part of the explanation of these low manpower requirements is due to the physical proximity of the reactors. These three reactors share manpower and, therefore, make more efficient use of the personnel. Reactor Operations Departnent employees are not considered. 
fully trained until they can work effectively at any of the three reactors; thus, greater eficiency is attained. It is never necessary to hold specially trained reactor operations personnel in reserve, in ialeness, until a given reactor requires their particular talents. The proximity of the reactors to each other has also made it surprisingly easy to operate the IIIR and the OGR from the same control desk for the past six years. A reduction in personnel requirements of approximately four men resulted from the combination of these two control desks.

It should be pointed out that reactor experiments are not operated by the operations group. Howsver, at times, Operations provides assistance to experimenters for certain routine tasks.

\section{Mechanical Maintenance Marpower}

During operation of the reactors, approximately eight manhours per day are required at the IITR and the OGR for reactor mechanical maintenance; whereas, 48 manhours per day are required at the ORR. Maintenance of ORR experiments requires approximately 170 additional maniours per day.

Maintenance work at the ORR is initiated by the reactor supervisor through the day foreman who provides a iist of required work to an assigned maintenance foreman one week prior to the time the job is to be done. In addition to a maintenance foreman, an engineer is available to provide technical assistance. The engineer, foreman, and craft personnel are furnished by the Engineering and Mechanica! Division.

A long shutdown is scheduled every four weeks at the LITR and every eight weeks at the ORR. During the monthly two-to-three day shutdown at the LITR, an average of 30 manhours of reactor maintenance and an average of 50 manhours of experiment maintenance is required. During the one-week 
shutdown at the $\mathrm{ORR}$ an average of 200 manhours on reactor maintenance and an average of 800 manhours of experiment maintenance is required.

Because of the smaller number of experiment facilities at the IITR, a less detailed shutdown work schedule is required than for the ORR.

Due to tie amount of work and the number of people with different interests involved in an ORR shutdown, much more careful scheduling is necessary. Here the schealule must include craft requirements, manhours, timing, and tine level of the pool water necessary for each task. ${ }^{8}$ Approximately 100 manhours are required by members of the Operations, Engineering and Mechanical and Instrumentation and Controls Divisions to prepare a detailed schedule for the one-week shutdown. During an average shutdown, the Engineering and Mechanical Division assigns four engineers and five foremen to provide field engineerine and supervision. Shutdown information for the three reactors is listed in Table 4.

Table 4. Operating Data

\begin{tabular}{lcrr}
\hline \multicolumn{1}{c}{ Reactor } & ORR & OGR & LITR \\
\hline Power, MWt & 30 & 3.5 & 3 \\
Operating time, of & $\sim 80$ & -90 & $\sim 88$ \\
Maintenance shutdowns per year & 6 & 52 & 13 \\
Duration of maintenance shutdowns-.days & $\sim 7$ & $\sim 0.5$ & $\sim 2$ \\
\hline
\end{tabular}

In Table No. 5 a complete breakdown of all maintenance labor for a one ayear period is given. The ORR utilized 7191 mandays, the LITR 1402, and the OGR 1125. 


$$
\text { -il- }
$$

Table 5. Breakdown of Reactor Maintenance Labor for One Year

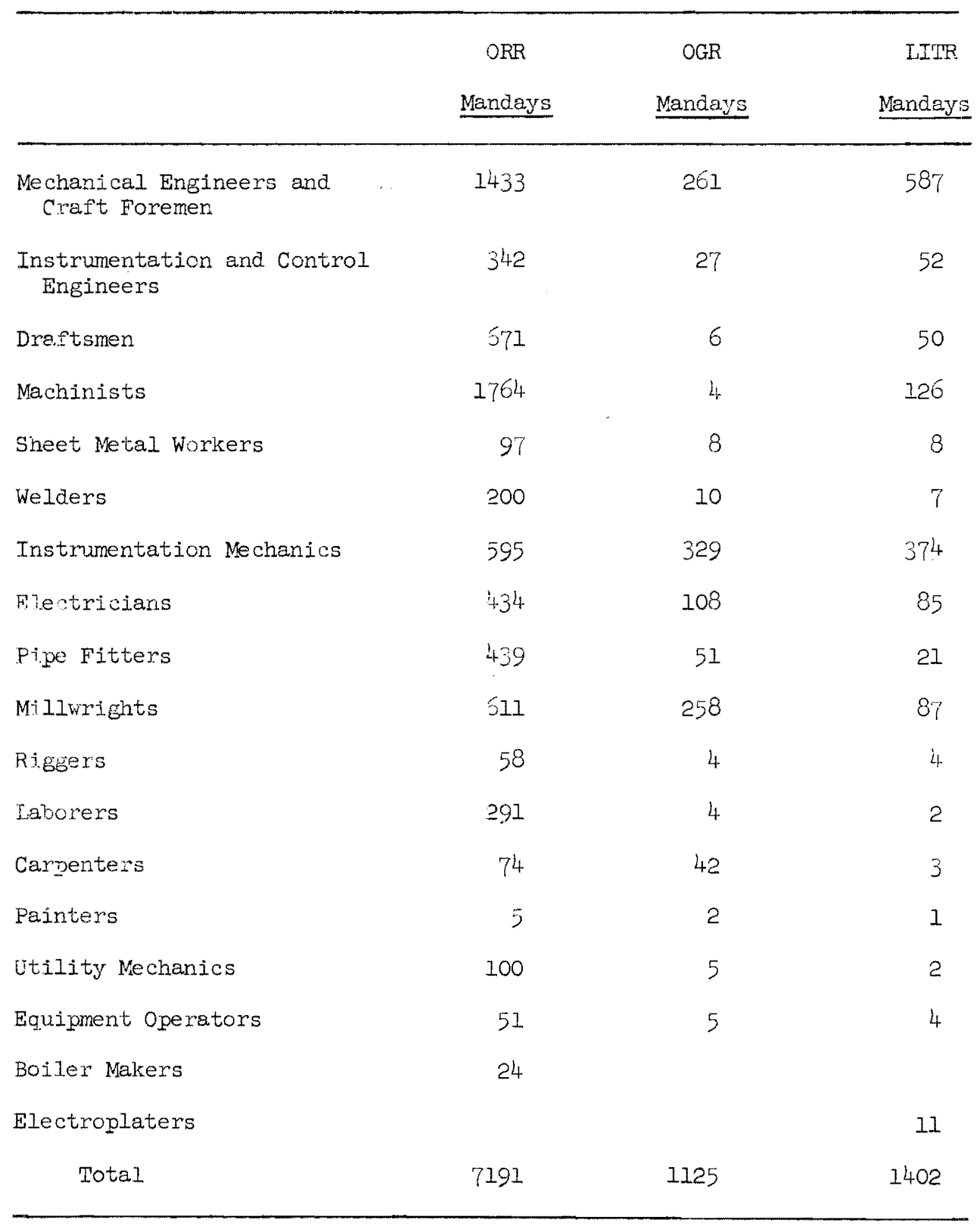


OGR manpower requirements for maintenance is somewhat less than that for the IITR because after 18 years of operation most necessary changes have been completed and most of the unreliable equipment has been replaced. The reduced number of changes is further illustrated by the fact that the number of manhours of drafting time was 671 for the ORR, 50 for the IITR, and 6 for the OGR.

Table 6 shows the number of mancays expended by instrument engineers and instrument mechanics on the three reactors for this twelve-month period. Table 6. Instrument-Maintenance Manpower Used in One Year

\begin{tabular}{lcc} 
Reactor & $\begin{array}{c}\text { Instrument Engineers } \\
\text { Mandays }\end{array}$ & Instrument Mechanics \\
\hline ORR & 342 & Mandays \\
IITR & 52 & 395 \\
OGR & 27 & 329 \\
\hline
\end{tabular}

The disparity of electronjc-engineering needs between the three reactors is easily explained. The ORR, being a high-flux reactor with all of the attendant xenon problems, cannot tolerate frequent shutdowns. To avoid unnecessary shutdowns, a program of preventive.maintenance has been developed and is still being improved. After the reactor has been operated For a number of years, these engineering requirements should decrease.

III. OPERATING PROCEDURES, THEIR DEVELOPMENT AND REVISION

\section{A. The Need for Procedures}

Operation of the research reactors is continuous: 24 hours a day, seven days per week. Jobs must often be passed from shift to shift, and a 
system of unambiguous communication is necessary to ensure that every supervisor has the necessary information. Also, reactor operation is accompanied by all the normal industrial hazards. Coupled with these are the problems of radiation, contamination, and criticality. Furthermore, it is usually important that the reactors be operated at full power as much of the time as possible.

\section{B. Description of Procedures}

1. Published Procedures

In order to ensure that the operation of the reactors is carried on in a well-regulated manner, arrangements must be made for providing the proper procedures and for revising them as needed. The operation of research reactors should be made as routine as possible so that the customers (the experimenters) can predict with some confidence the future conditions of the reactor. Well-developed procedures for operation help establish this routine and also help ensure safe operation. Because they are written for use by the reactor cperators the procedures must (to some extent) be prepared in non-technical language. Procedures, aside from outlining the step-by-step operation, contain the following three categories of information:

1. Understandable reasons for the method of operation;

2. Special hazards, if any; and

3. References to descriptive material, blueprints, etc.

The operating manual for the Oak Ridge Research Reactor ${ }^{9}$ is divided into the following sections: 


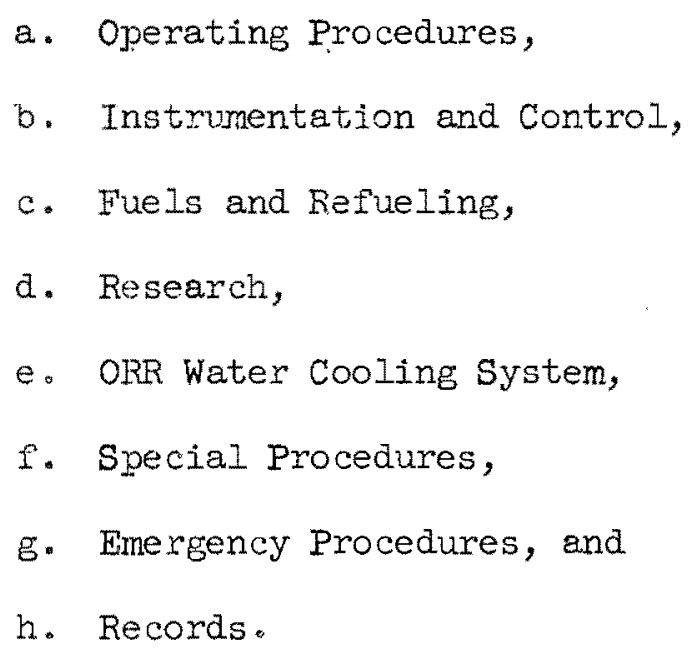

In Appendix I there is a brief description of each section.

\section{Procedure Changes}

With new reactors many special procedures must be developed in addition to those prepared at the time of initial startup. Table 7 shows the number of procedures and procedure revisions written for the ORR during each year from 1958, when the reactor first went critical, to the present. As would be expected, many new procedures were necessary during the first year. In September of 1960, the power level of the ORR was increased from 20 to $30 \mathrm{M}$. This caused an increase in the number of procedural changes in 1961. New procedures are needed for a variety of reasons including:

1. Design changes,

2. Desire to standardize certain procedures to increase safety,

3. Need for transferring operating responsibility from the technical staff employed during startup to the operating staff which includes many nontechnical reactor cperators, and

4. New personnel taking over jobs perviously held by more experienced people. 
Table 7. Number of New ORR Procedures Issued Per Year

Year

Number of New Procedures

1958

94

1959

57

1960

36

1961

57

1962 (through April)

9

As changes and additions to the procedure manual becone necessary, they are issued as procedure memoranda, so called because they are written in a somewhat less formal manner than the procedures themselves and are not edited as carefully as the published procedures. Each procedure memorandum is issued separately, as needed, and is assigned a number, in series, for the reactor it concerns. Any supervisor may originate a procedure memorandum, but the reactor supervisor must review and approve a.l memoranda which affect his area. In addition, approval by the Reactor Operations Department Superintendent is required for all procedure memoranda issued within his department. 3. Checklists

The checklist is a special type of procedure. Usually those procedures chosen to be issued as checklists apply either to complex operations where mistakes cannot be tolerated or are for the purpose of checking important details of the operation. Some of the checklists, such as those used during reactor startup, are considered so important that the supervisor must complete the list himself. Most of the lists, however, are completed by a reactor operator and reviewed by the shift engineer. 
Following is a list of the titles of the 13 checklists in use at the ORR (At the IJIM there are 10; at the OGR, 5.):

I. Startup checklist,

2. Shutdown checklist,

3. Daily water system checks,

4. Weekly checks,

5. $12-8$ shift daily checklist,

6. 8-4 shift daily checklist,

7. 4-12 shift daily checklist,

8. Daily instrument checklist,

9. North and south facilities,

10. Shim-rod removal checklist,

11. Shim-rod insertion checklist,

12. Experiment safety checklist, and

13. Beam-hole status checklist.

In Appendix II there is a set of the checklists for the ORR.

IV. DISTRIBUTION OF INTERNAI INFORMATION

OF TEMPORARY IMPORTANCE

A. Needs for Temporary Information

As outlined under Manpower and Organization, many people are required in order to operate a reactor. Good distribution of information among personnel is, therefore, imperative. The supervisor must make his orders known and understood, and each person must, in turn, keep his supervisor informed about the progress of the work. Most of the knowledge transmitted during daily operation can be compared to news in a newspaper. It is useful, educational, and interesting at the time but usually not of 
continuing value. On the other hand, procedures as described above contain more lasting material. One might compare internal information to newspapers and procedure manuals to textbooks.

B. Methods for Communicating Internal Information

\section{Logbooks}

The basic method for keeping abreast of detailed information whether temporary or not is by use of logbooks. Such a book is kept for each reactor, and the daily work of the shifts is described in these books. The result is a minute history of the operation. Much of this passes into oblivion and is not used after the next day of operation; however, at times apparently useless observations, properly documented in the logbook, become most important in explaining an unusual occurrence. Categorizing the ORR logbook information under the following headings has been found to help the reader:

1. Operations,

2. Shutdowns,

3. Trouble,

4. Maintenance,

5. Service to research,

6. Routine checks

7. Irradiated samples, and

8. Miscellaneous.

Frequently, it is necessary to search through the logbook to find such things as the number of instrument failures, the number of times the reactor has been scrammed through human error, the extra hours of work for a special project, or exactly when some phenomenon occurred. To facilitate 
searches of this type, it is helpful to have the material of the log divided into generel categories.

2. Operating Instructions

Instructions to shift crews are written on a form provided for this purpose and titled Operating Instructions. Operating instructions are conspicuously posted in each of the reactor control rooms. They are among the first items to be examined when the shift supervisor comes on duty. For clarity and emphasis these instructions are typed if possible. 3. Experiment Information Sheet

As outlined in Section IIC, the Operations Division does not have responsibility for operating experiments. Most reactor experiments at ORNL are provided with instruments which make continuous surveillance unnecessary; however, certain experinents may require constant attention. It is important that the experimenter and the Reactor Operations Department have procedures detailing the action required under various conditions. Experiment Information Sheets are used for this purpose and a compilation of these sheets is kept in each control room. 4. Sample Scineduling

Target materials for exposure in the ORR on a short wterm basis (usually in the hydraulic tubes) are delivered to the day foreman who assigns them a serial number and has this number inscribed on the specimen container. An individual specimen sheet is filled out giving complete information for the insertion and removal. These sheets are consulted at the beginning of each shift by the shift engineer or the shift foreman as they begin planning the work of the shift. 
5. Shutdown Schedules

During shutdows it. is sometimes necessary to accomplish a great many tasks that can only be done during this period and have therefore accumulated since the last one. For all scheduled shutdowns, the reactor supervisor prepares a detailed schecule of the work to be done, including the tests required to assure that the work was properly done.

V. ADMINISTRATIVE CONTROL OF SAFEIY

A. Reactor Safety

Accidents that occur in nuclear installations usually receive more attention than those that happen in other industries. Table 8 contrasts the safety records of the AEC contrectors and of the chemical industry. Table 8. Safety Record Compairson for 1950-1960

Organization

Disabling Injuries Per I, 000,000 Manhours
Days Lost. Due to Injuries Per 1,000,000 Manhours

Chemical Industry 3.53 528

Union Carbide Corporation

2.10 429

AEC Production

1.13 118

AEC Research

1.86 274

ORNL 1.07 113

It is evident that all AEC work has a better safety record than that of the Union Carbide Corporation which is considerably better than the chemical industry of which the corporation is a part. It is significant that over its 19 year operating history the ORNL record contains no incident of a lost time accident for nuclear cuases. 
Even with this enviable safety record, reactor safety must continue to be one of the important problems of operation. There are four parts to the problem:

I. Proper selection and design o: säeguards, 1

2. Detection of saleguard failures,

3. Checking or safeguards, and

4. Administration of the preceding three.

B. Administrative Support for Mechanical

and Electronic Safeguards

Procedures for effecting reactcr safety are well covered in "General. Standards Guide for Reactor Experiments at ORNL" ${ }^{1}$, "Personnel Exposure and Contamination Control in the Routine Operation of the ORNL Research Reactors"2, and "Problems Encountered During Four Years of ORR Operation" 8 . The final list of all the procedures, checklists, trainine manuals, safety reviews, safety reports, etc., is impressive; but these alone do not ensure safety. People must read, understard, and follow the principles, rules, and directions that are contained ir these documents. It is not possible for a supervisor to be absolutely certain that all operations are always performed correctly. The personnel who execute the tasks must be trained so that they understand and accept their responsibility .

An axiom of reactor operations is: A safeguard that cannot be tested is worse than none. For this reason a reliable system for performing such tests must be maintained. Adninistrative support helps guarantee that approved safezuards are properly employed and checked. 
VI。 COSTS OF REACTOR OPERATIONS

A. Simplifiea Desoriptions of Various Types of Cost ${ }^{20}$

At the Oak Ridge National IEboretory, reactor operating costs

include all direct and indirect costs associated with the routine maintenance and operation of rise reactor. Costs of uranium, depreciation, and. interest charges are not inciuded, however.

Equipment items purchased in connection with reactor operations are customarily capitalized and are not charged to operating funds if they cosi more than $\$ 1,00$ and have an estimated life greater than one year. Iowever, equipment which will be cendered unfit for other application by some result of their original usage is not capitalized. An example would be induced radioactivity of radioactive contamination of equipment.

B. Description of Operating Costs

1. Total Operatine Costs Bor Reactor Operation Department

Table 9 sumarizes the total orerating costs of the ORR, IITR, and OGR for the year from september, 1960, through August, 1961.

Table 9. Reacion Operations Department Operating Cost From September 1960, through August, 1961

\begin{tabular}{lccc}
\hline & $\begin{array}{c}\text { Oak Riōge } \\
\text { Research Reactor }\end{array}$ & $\begin{array}{l}\text { Low-Intensity } \\
\text { Test Reactor }\end{array}$ & $\begin{array}{c}\text { Oak Ridge } \\
\text { Graphite Reactor }\end{array}$ \\
\hline Labor & $\$ 420,000$ & $\$ 96,500$ & $\$ 118,300$ \\
Material & 268,000 & 23,500 & 31,600 \\
Overhead & 286,000 & 65,100 & 79,500 \\
Other & 111,000 & 42,300 & 112,500 \\
Total & $\$ 1,085,000$ & $\$ 227,400$ & $\$ 341,900$ \\
\hline
\end{tabular}


2. Breakdown of Operating Costs for the ORR

A more complete hecakdown of ORR costs developed from the monthly operating costs reports is given in Table 10 .

Table 10. Breakdcwn of ORR Costs:

September 1, 1960, through August 30, 1961

Labor

\begin{tabular}{lr} 
Operating & $\$ 198,000$ \\
Maintenance & 200,000 \\
Other & 22,000 \\
\hline
\end{tabular}

Total

$\$ 420,000$

Material

\begin{tabular}{lr} 
Operating & 168,000 \\
Maintenance & 80,000 \\
Miscellaneous & 20,000 \\
\hline
\end{tabular}

Total

$\$ 268,000$

Overhead

286,000

Health Physics

23,000

Workeà Material

61,000

Utilities

27,000

Total

$\$ 1,085,000$

Labor costs have been divided into the following categories: departmental or operating, maintenance (including mechanical, electrical, and instrument), and other or miscellaneous labor.

Material costs are those incurred in the performance of the labor outlined above. Maintenance material cost covers the normal wide variety 
of supplies required for any major maintenance work. Expense allocetion or overheed costs are distributed as a percentage of the labor charged to the account. For the year considered that amount was approximately $64 \%$ of the labor costs.

Utilities inciude charges for electricity, water, and steam. The ORR is charged approxingtely $\$ 1000$ a month for water at the rate of 13 cents per thousand gallons. All other utility costs are allocated to the ORR on the basis of labor costs.

of the Health Physics costs, surveying and monitoring for radiation and radioactive contamination around the reactor accounts for $70 \%$ of the charges. Area monitoring, health plysics laboratory analysis, and personnel monitoring, about evenly aivided, make up the remainins $30 \%$ of ORR costs from this source.

The costs of fissionable-material accountability, equipment decontamination, demineralized water, and radioactive-waste disposal are collected under "Worked Material".

\section{Variable Costs}

Operating costs for a research reactor such as the ORR tend to be fairly constant. Fuel costs, however, are variable because fuel elements are purchased commercially in large numbers.

Another source or unusual costs occurs when equipment wears out or new developments and designs require replacement. Most of these variations in costs come from the maintenance of the reactor. 


\section{Distribution of Costs}

1. Background

During the last is years of operation of research reactors at ORNL various systems of cost distribution have been devised. The first was based on reactor space, themal-neutron flux, and reactivity effects of the experiment. In the beginning this was reasonable because most experiments at that time consisted mainly of irradiating an apparatus in the reactor. However, beam experiments did not have any effect on reactivity; and installations such as the thermal column used no reactor space, had no effect on reactivity, and had a flux much lover than the average for the reactor.

Next a method that was based on space and thermal-neutron flux was developed. For the LITR this system worked well until complex experiments requiling coolant and information leads were installed in the reactor. It soon became obvious that using only space and flus also resulted in inequities in cost distribution. The system finally developed for the

ORR is more empixical than the initial methods. 2. ORR Cost-Distribution System

To make the ORR a hisily versatile and adaptable reactor for use in experiments in basic science and engineering, many types of facilities vere provided. All these facilities have been assigned relative cost units wich are utilized to allocate costs to the experimenters. A close examination of units as show in Table 12 reveals that there is a degree of relationship between space and the value of units for reactor facilities. There is no formula for arriving at this however. The beam holes and the pool facility occupy opposite sides of the reactor and have been 
assigned roughly equivalent cost units. This also applies for the other two sides-athe large beam holes having the prefixes HN and HS. Core positions tctal 20 cost units which is less than the total for all facil: ities on the periphery. In addition to these units, there are those for the hydraulic tubes, reactor-tank ports, standpipes, and floor space. The hydraulic tubes occupy only one core position, but they use a reactor tank port and are operated by the department. Therefore, the cost units are higher than for a single core position. It was possible to provide only 10 exit ports in the top of the reactor tank for experiments which require continuous monitoring. Because of the short supply of the important type of facility and because the complicating factors introduced into the operation of the reactor by experiments of this type, extra charges are made for these ports. Standpipes are large 24 -inch conduits which permit experimenters to have access to the ORR basement with $100 \mathrm{p}$ cooling lines. Charges are made for the use of these standpipes for the same reasons that increase the cost to experimenters who use reactor tank ports. Around any reactor, floor space in the immediate vicinity of the reactor Pacilities is in high demand. Laboratories in the building have a somewhat lesser demand. Special facilities such as the counting room and the hot laboratory had a higher initial cost than offices and normal laboratories and therefore have higher cost units assigned to them. This system has worked excepticnally well and has proven quite simple. 
Table 12. ORR COSt Units

\section{Units for Each Total}

\section{Recictor Space}

20 Core positions

$\mathrm{HB}-1,2,5$, and 6 beam holes

$\mathrm{HB}-3$ and 4 beam holes

HS large beam hole

$\mathrm{HN}-\mathrm{I}$ and 4 beam holes

$\mathrm{HN}-2$ and 3 beam holes

$\begin{array}{lr}1.0 & 20 \\ 2.0 & 8 \\ 2.5 & 5 \\ 7.0 & 7 \\ 3.5 & 7 \\ 0.5 & 1\end{array}$

Fool Facility

$P-1,2,3,7,8$, and 9

1.0

2.0

6

$P=4,5$, and 6

6

Hydraulic pubes (Including one reactor tank port and one core position)

in, the and

$\begin{array}{ll}1.0 & 3 \\ 2.0 & 2\end{array}$

Suistotal

65

Reactor Tank Ports (Used for experinents having tubes connected to core positions)

$v-7,3,7,8$, and 9

$1-2,5,6,10$, and 11

0.5

1.0

2.5

Subtotal

5.0

1.5

Standpipes (Used for loop piping to equipment cubicles in basement)

Soutin

North

$N-1,2,6$ and 7

$N-3,4$, and 5

Subtotal

\section{E]oor Space}

$O$ (plus) Basement bays

4 Beam-hole areas

$\therefore$ Beam-hole area $(\mathrm{HB}-2)$

- Bean-hole area ( $\mathrm{HB}-6)$

2 Iarge-fauility areas

1. Counting room

1. Hot Laboratory

$? .8$ First-level bays

12.5 Second- and third-level laos

Subtotal
$5.0 \quad 5$

1.0

0.33

4

1

10

0.

0.25

0.13

0.5

0.5

1.0

1.0

0.25

0.25

13.79
4.05

1.00

0.13

0.50

1.00

1.00

1.00

1.96

3.15

$\begin{array}{cc}\text { Total } & 96.29\end{array}$ 
VII. ADMINISTRATIVE CONTROL OF RADIOACTIVE WASTE

A. Types of Radioactive Waste Produced at the ORR

Liquid radioactive wastes at the ORR are classed as: process waste and intermediate-level waste. Gaseous wastes are termed off-gas and cell ventilation. 12 Process-waste water may contain small amounts of radioactive contamination but has a possibility of becoming more contaminated. Intermediate-level-waste water is definea as having a concentration of less than ten curies yer gallon but, in practice, that producea at the reactor averages about $10^{-4}$ of this value. Opf-gas wastes may contain a large amount of contamination but volumes are low and the system pressure is quite negative. Cell ventilation, on the other hand, is characterized by small amounts of contamization and large volumes, at relatively Iow negative pressure.

Tables 13 and 14 show the estinates of the volumes of intermediateJevel waste (sometimes called hot waste), process, and gaseous wastes produced by normal ORR operation. There are two designations for off-gas in Table 14, normal and pressurizable. ${ }^{8}$ The pressurizable system is capable of containing gas at pressures up to 100 psid with respect to atmospheric pressure.

\section{B. Control of R dioacrive Wastes at the ORR}

Primary control of radioective wastes is exercised administrativeiy. on a monthly basis a material balance between the measured total volume from the reactors and the estimated total volume from individual sources is made. Usually it is not possible to account completely for the measurea total. If there is an urgent need to reduce volumes a determined effort is made to identify all sources and to reduce the discharge from as many sources as possible. This is done by rechecking all of the tabulations 
Table 13. Sources and Volumes of Radioactive Liquid Waste

\begin{tabular}{|c|c|c|}
\hline Source & $\begin{array}{l}\text { Volume } \\
\text { gallons/month }\end{array}$ & \\
\hline \multicolumn{3}{|c|}{ ORR Intermediate-Ievel Waste } \\
\hline Degasifier effluent & 22,000 & \\
\hline Demineralizer regeneration effluents & 6,000 & \\
\hline Underwater saw purge & 2,000 & \\
\hline Total & & 30,000 \\
\hline \multicolumn{3}{|c|}{ ORR Process Waste } \\
\hline Water-sealed vacuum pump seal flow & 130,000 & \\
\hline Demineralizer regeneration effluents & 7,000 & \\
\hline $\mathrm{HB}-3$ diffusion-pump coolant & 302,000 & \\
\hline $\mathrm{HB}-1$ diffusion-pump coolant & 129,000 & \\
\hline Degasifier condenser coolant & 130,000 & \\
\hline Miscellaneous ${ }^{a}$ & $2,130,000$ & \\
\hline Total & & $2,828,000$ \\
\hline
\end{tabular}

anmeasured and unestimated amounts of water go into the process waste system from the following sources: corrosion test stand, $\mathrm{HB}-1, \mathrm{HB}-6$, HB-5, Loop No. 1, MSR Experiment, Grinking fountains, wash basins, laboratory sink, welding machines, underground water seepage, air compressor, pump leakage, and Loop No. 2. Thus far it has not been necessary to go to the expense of cotaining accurate information on these flows. 


$$
-29-
$$

Table 14. Radioactive Gaseous Waste

\begin{tabular}{|c|c|c|}
\hline Source & $\begin{array}{l}\text { Volume } \\
\text { scfm }\end{array}$ & \\
\hline \multicolumn{3}{|c|}{ ORR CeII Ventilation } \\
\hline MSR Experiment equipment chamber & 1,000 & \\
\hline B-9 Experiment equipment chamber & 900 & \\
\hline Building ventilation vents & 4,500 & \\
\hline Total & & 6,400 \\
\hline \multicolumn{3}{|c|}{ ORR Off-Gas, Normal ${ }^{a}$} \\
\hline Loop No. 1 & 30 & \\
\hline P-6 (pool-side experiment) & $<1$ & \\
\hline B-8 (in-reactor experiment) & $<1$ & \\
\hline Beam holes & Unknown & \\
\hline Total & & $\sim 30$ \\
\hline
\end{tabular}

${ }^{\text {a }}$ Pressurizable off-gas system is not in service yet. 
of volumes of waste and $b_{y}$ sampling wherever possible. A multichannel analyzer is used for quick qualitative identification of the radionuclides. Samples are also submitted for a more quantitative analysis by beta counting.

In designing waste systems, it is important to include means for visually checking the flow at as many points as is economical. Also any new design should include sampling points and, in some cases, facilities should be provided for future installation of continuous monitoring systems for measuring flow and/or radioactivity. Since the volume and degree of contamination of radioactive waste dictates the stringency of control, it should be possible to completely stop any radioactive waste effluent if necessary. Furthermore, the designer of waste systems should remember thet the established limits for disposal of vastes may be lowered and, thus, the system may require closer control in the future.

\section{VII。 SUMMARY}

The administrative methods for the operation of ORNL research reactors necessarily apply to those specific reactors. There is enough similarity among reactors, however, that the principles of administrative control should be applicable on a broad scale. Many of the methods of adminis tration of research reactors are similar to the approach for most types of operating organizations: a system of ideas is assembled for accomolishing the goals in a saie, efricient manner, and a staff which has the responsibility for attaining these goals is selected and trained. 


\section{REFERETVES}

1. C. D. Cagle, General Standards Guide for Reactor Experiments at ORNI.*

2. T. M. Sims, Personnel Exposure and Contamination Control in the Routine Operation of the ORNL Research Reactors.*

3. F. T. Binford, Training Programs for Reactor Operation and Reactor Hazards Evaluation at the Oak Ridge National Laboratory, presented at the symposium on the Programing and Utilization of Research Reactors, I AEA, Vienna, Oct., 1961 (to be published).

4. E. N. Cramer, An Analysis of Treining Programs in the Operation Division at ORVL.*

5. I. E. Stanford, Safeguard Report, on the Proposed Method of Annealing Graphite in the $\overline{\mathrm{X}}-10$ Reactor, OFNL 2725 Revised Reactors - General (May, 1960).

6. A. L. Colomb and Doyle Cavin, Loading Programming for Water-Cooled Research Reactors.*

7. A. L. Colomb and F. T. Binford, The Detection of Boiling in a WaterCooled Nuclear Reactor.*

8. W. H. Tabor and R. A. Costner, Jr., Problems Encountered during Four Years of ORR Operation.*

9. W. H. Tabor, et al, Operating Manual for the Oak Ridge Research Reactor, ORNL CF 60-8-46 (Sept. 30, 1960).

1.0. W. E. Thompson, Private Communication, (April, 1962).

1.1. Standard Practice Procedure, Oak Ridge National Laboratory, Number 3C, Part III.

3.2. J.F. Manneschmidt and E. J. Witkowski, Radioactive Liquid and Gaseous Waste Disposal at the Oak Ridge National Laboratory.*

\footnotetext{
*Paners presented at the "Conference on Light-Water-Moderated Research Reactors," ORNL (June, 1962).
} 


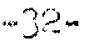 \\ IX. AFFEIDIX I \\ A. Description of ORR Procedures}

The operating manul for the ORR is divided into elgit sections:

operating Procedures,

Instrimentation and contiol.

Fueis and Refueing;

Researcin,

ORR Water-Cocling System,

Speciel Procedures,

Emercency Procedures, and

Recotis .

\section{Operating Procedures}

In a detailed, step-by-step maner, procedures ron reactor start-up, shut-down, and steady-state operatin are given. Responsibilities and hazards are outlined and spectic instructions are given for specjal startups such so those following a yel reloeding and those followine a shutewn due to an accidental droppsin of the shin rods. Also, detailed incormation is Given for shutting the reactor down sud for disassembling the reactor for shutdom wok. The gystem for reporting accidental sintdums is descrined. Duries of the oporating crevs are outlined giring proper instruction for aeat-porex celculation, adjustment of instruments, and procedures for coninuous operation.

2. Instrumentation and Control

Al] the reactor instmmentation is explained in enough detail that the operating crew can detect malrunctions as well as use the instruments in the operation of the reactor. Separate detailed maintenance manuals are prepared for the maintenance start. 
3. Fuels and Refueling

Handling and storage rules and procedures are included along with methods for reloading the core.

4. Research

Procedures for the routine operations connected with research facilities are found in this section. Also covered here are the tasks to be performed for the isotope productior program.

5. ORR Water Cooling System

Complete information for the operation of the reactor and pool primary and secondary water systems and the reactor and pool demineralizers is given.

6. Special Procedures

Procedures for such jobs as working in the ORR pool, detecting water leaks at large facilities, and operation of the pneunatic doors and air conditioning systems are included.

7. Emergency Procedures

Operation of the emergency power and ventilation systems is explained. The equipment provided for "after-heat" protection is described, and procedures for operation are given. Emergency evacuation procedures also appear in this section.

8. Records

A complete description of each data sheet is given along with instructions and procedures for the $r$ use. 
$-34-$

X. APPENDIX 2

A. ORR Checklists

A set of $13 \mathrm{ORR}$ checklists is included in this appendix. 


\section{CHECK IIST 1}

NOTE: Person making startup checks initial each check after completion.

Date

A. Tank Area

1. All core pieces in place and properly seated.

2. Experiments properly arranged in reactor tank.

3. Hold-down arms properly seated and locked.

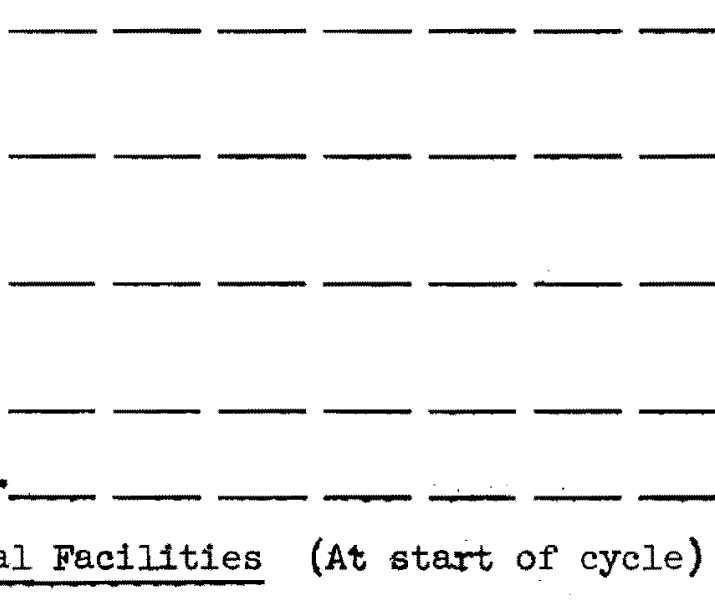

1. All experimental changes completed.

2. Experimental information sheets completed.

3. Individual experiments safety check sheets completed by instrument engineers.

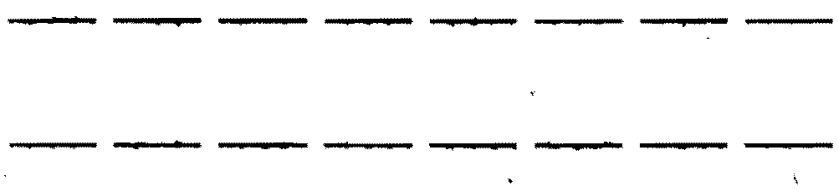

1. Reactor pool filled to proper level.

2. All pool alarms cleaved.

3. Pool clrculating system ready for service.

4. Pool deminerallzer in service.

5. Reactor system filled and vented.

6. Reactor water flow established.

7. Degasifier in service.

8. Reactor demineralizer in service.

9. Both secondary coolant loops plled, treated, and ready for service.

10. Flow through bypass filters. 
11. Reactor primary bypass valve system in automatic and temperature setpoint established.

12. Reactor secondary system in automatic; temperature setpoint established.

13. Cooling water to horizontal beam holes (refer to status sheet).

14. Cooling water to north facility.

15. Cooling water to south facility.

16. Subpile room:

--Demineralized water supply to drive seals.

--Demineralized water supply to annulus of bottom plug.

\section{$\longrightarrow$}
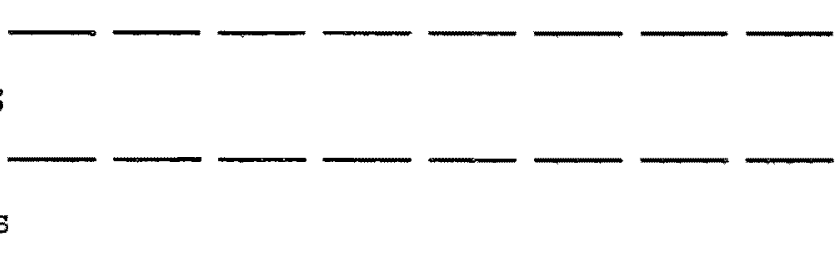

-Demineralized water supply to fission chamber.

--Servo tachometer plug connected to servo rod drive motor.

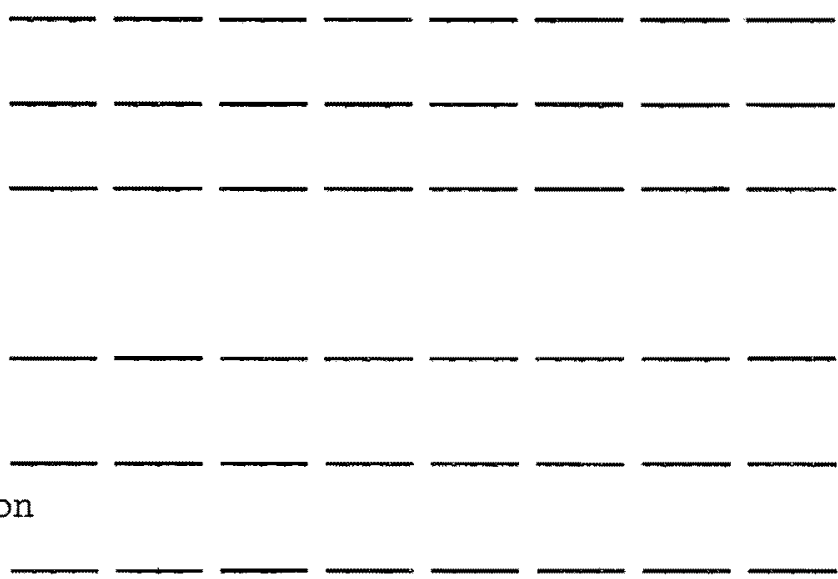

\section{Instrumentation Checks (*Before start of cycle)}

1. All utility services in order:

--Power circuits L-3I through I-38 plus $I-39$ and $I-4 I$; located in front power cabinet.

--LX-1 through $\mathrm{IX}-6$; located in front power cabinet.

--I-I through $\mathrm{L}-12$ pIus $\mathrm{L}-14$ and $\mathrm{L}-16$; located in rear power cabinet.

$-\infty$ Air supply.

2. AII nuclear instruments turned on at least $1 / 2$ hour prior to operation of the reactor.

3. Ionization chamber positions. Check $\log$ book for any movement during shutdown.

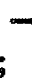
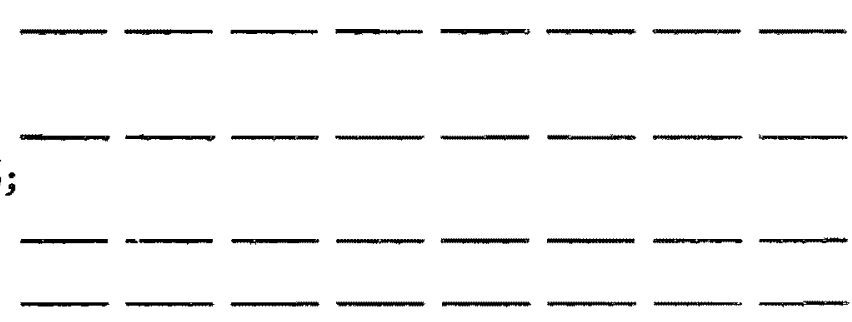

Log $N$ calibrated and set on "operate".

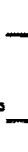

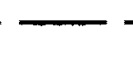

-

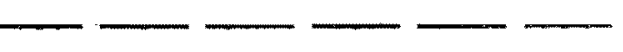

*5. Safety channels \#1, \#2, and \#3 calibrated.

*6. CRM calibrated by recorder and set on "USE". 
F. Shielding Checks

*1. HB-1 through $\mathrm{HB}-5$ shield blocks in place.

*2. HB-6 shield closed and key in possession of Operations.

3. HN shielding in place.

4. IS shielding and monttrons in place and checked.

5. Pipe chase closed.

* Or collimator flooded with water valves locked open

\section{G. Checks on Count Rate Channels}

1. Pool side fission chamber inserted.

2. Pool side count rate speaker activated and working. 
CHECK LIST 2

ORR SHUTDOWN CHECK LIST

Date

Initial

1. Scram handle in "scram" position.

2. Key switch in "off" and key removed.

3. All rods in seat position and seat lights "on".

4. All rod mode switches in "off" position.

5. Servo demand at $\mathrm{N}_{\mathrm{I}}$.

6. After 30-MW operation:

A. Continue normal circulation of reactor water for 30 minutes or until the temperature of the reactor water is equal to the pool temperature; i.e., $78^{\circ} \mathrm{F}<$ outlet temperature $<100^{\circ} \mathrm{F}$.

B. Complete the "test" on emergency cooling units (end-of-cycle shutdowns only).

c. Unit \#1

Unit \#2 Check to determine that DC motors turn the pumps Unit \#3

after AC motors are stopped.

D. Unit \#1 \&

Unit \#2 "Charger-battery" disconnects closed. Unit \#3

E. Unit \#I, Unit \#2 "Battery-motor" disconnects opened.

7. Reactor secondary 10op.

A. Fans in "off".

B. Pumps in "off".

C. Blow-down valves closed.

D. Acid addition system "off".

8. Pool secondary loop.

A. Fan in "off"。

B. Pump in "off".

C. Blow-down valve closed.

D. Acid addition in "off".

9. Main pumps "off".

10. Shutdown pump "on".

11. Main pump test blocks removed.

12. Channel $\# 1$ )

Channel \#2 Log-N amplifiers on ground position.

13. Subpile fission chamber Inserted to give $20 \mathrm{cps}$. 
14. Pool-side fission chamber inserted to give $20 \mathrm{cps}$.

15. CRM speaker at pool-side activated. 
CHECK IIST 3

Day

Operator

ORR DAILY WATER SYSTEM CHECKS

$\underline{\text { Reactor System }}$

Control Room Pump House

Tank $\Delta P$

psi。

Bypass fllter flow (gpm)

Tank top pressure ps1. Primary flow (gpm)

Fac1lity cooling flow gpm. Reactor exit temp. ${ }^{\circ} \mathrm{F}$

North demineralizer flow gpm, Integrator (

) $x(1.5)=$ gals .

South deminerallzer flow $\mathrm{gpm}$, Integrator $(\quad) \times(1.5)=$ gals.

Stringer $\Delta P$

(inlet)

$-(\operatorname{ext} t)$ $=$ psi.

Primary Pumps \#1 \#2

\#3 Shutdown Emergency

Exit psi

Inlet psi

Motor amps

Bearing temp.

(North

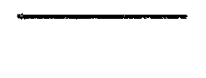
政
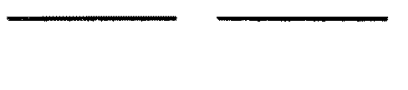

Bearing $t$ mp.

(South

Secondary mean temperature

${ }^{\circ} \mathrm{F}$ Pump exit (P156) psi. Return line (PI) psi.

\section{Pool System}

Primary flow gpm Secondary flow gpm Demineralizer (flow $_{\text {integrator }}^{\mathrm{gpm}}$ $x(1.8)=$ gals.

Recorded in Log Book

(Sump counts, deminerallzer data,

(All main pump DC battery cells SpG read, lowest logged 
Leak-Detector System for Large-Facility Plug

Inlet air press

Color of aryrite

Check for proper air purge through the beam-hole liner. 


\section{CHECK IIST 4}

WEEKLY CHECKS

Check if "OK"

Date

1. Underwater lights check

2. Secondary system supplies, check and reorder

3. Pool tools check

4. "Teletalk" system check

A. Room 307

B. Room 305

C. Room 303

D. Room 301

E. North side of pool

(Clear contact must be established)

F. South side of pool

(between the control and the point)

G. Health Physics Office

H. Second floor, west end

I. First floor, north

J. First floor, south

(in question. The ability of the)

(control room to contact each area)

(should be tested as well as the )

(reverse condition.

K. Subpile room

L. Outside subpile room door

M. Pipe tunnel

N. Reactor pump house

O. Reactor secondary pump house

P. Fus dontrol room

Q. Trane Coolers

5. PA system check

A. Third level

B. Second level

C. Toilets in 3042 Building

D. First level

(A man should be able to hear the)

E. Basement

$F$. Area outside northeast corner of building

G. Purmp house

(PA clearly and distinctly in any)

(and all of the locations listed.)

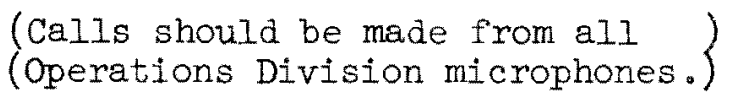

H. Storage tank area

I. Reactor heat exchanger area

J. Cooling tower area

6. Run emergency gasolire pump one hour

7. Gas cylinder check 


\section{2-8 SHIFT CHECK LIST NYO '5 5 DALCK SHEET}

DATE

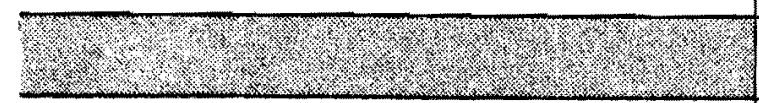

"Area checked for molfunctlons

\section{*EMERGENCY POWER SYSTEM:}

o. Tronsfer mode switch In "normal"

b. Dlesel mode swltch In "outo"

c. Fuel Valve of diesel polnted West

* Log and Clipboards checked for spec. assignments

*Batteries on DC 1 and DC 2

*Check sumps

*Experlment checks where necessary

*Demineralizer's pH and resistlultles logged

-Yellow hot cans emptled

* Dally repart for previous day complete

"Bullding CAMs and monitors operating

*All supplies checked

${ }^{*}$ Cutle-ples and survey meters

\section{*Off gas water traps}

o. Blow down catch tank

b. Fill seal tank

\section{*Storage tonk level}

Reactor and pool secondary system reodlngs logged

Corrosion test experiment

Degasifier in proper operotion

Cold tropsi reod and serviced

Cold traps, reod and serviced

Hyd. tube sample "In" and "out"

Purge specified Beam Holes

* To bo performed during shutdowns

UCN-227BA

(3) 10.801
FILLED OUT GY

\begin{tabular}{|l|l|l|l|l|l|l}
\hline SATURDAY & SUNDAY & MONDAY & TUESDAY & WEDNESDAY & THURSDAY & FRIDAY \\
\hline & & & & & & \\
\hline
\end{tabular}




\section{8-4 SHIFT ORR DAILY CHECK SHEET}

\begin{tabular}{|c|c|c|c|c|c|c|c|}
\hline \multirow[b]{2}{*}{ (4) } & \multicolumn{7}{|c|}{ FILLEO OUT GY } \\
\hline & FRIDAY & SATURDAY & SUNDAY & MONDAY & TUESDAY & WEONESDAY & THURSOAY \\
\hline \multicolumn{8}{|l|}{ Avo checked for malfunctions } \\
\hline \multicolumn{8}{|l|}{ "EMERGENCY POWER SYSTEM: } \\
\hline \multicolumn{8}{|l|}{ a. Transter mode swltch in "normol" } \\
\hline \multicolumn{8}{|l|}{ b. Dlesel mode switch In "outo" } \\
\hline \multicolumn{8}{|l|}{ c. Fuel Valve of diesel pointed West } \\
\hline \multicolumn{8}{|l|}{ * Log and Cllpboords checked for spec. ossignments } \\
\hline \multicolumn{8}{|l|}{-DC bottery check made and Sp. G. taken } \\
\hline \multicolumn{8}{|l|}{ *Check sumps } \\
\hline \multicolumn{8}{|l|}{ "Experiment checks where necessary } \\
\hline \multicolumn{8}{|l|}{ *Demineralizer -. Reactor } \\
\hline \multicolumn{8}{|l|}{ In Use } \\
\hline \multicolumn{8}{|l|}{ Ready TEST SGRUBRER PIIBPS } \\
\hline \multicolumn{8}{|l|}{ Being regenerated } \\
\hline \multicolumn{8}{|l|}{ *Demineralizer - Pool } \\
\hline \multicolumn{8}{|l|}{ In Use } \\
\hline \multicolumn{8}{|l|}{ Reody } \\
\hline \multicolumn{8}{|l|}{ Being regeneroted } \\
\hline \multicolumn{8}{|l|}{ "Dally woter system readings } \\
\hline \multicolumn{8}{|l|}{ * Storage tonk level } \\
\hline \multicolumn{8}{|l|}{ *Supplles ordered or obtained } \\
\hline \multicolumn{8}{|l|}{ "Radiafion survey } \\
\hline \multicolumn{8}{|l|}{ Pool and reacior secondary system readings logged } \\
\hline \multicolumn{8}{|l|}{ Reocior "on" lights shecked } \\
\hline \multicolumn{8}{|l|}{ Corrosion experlment } \\
\hline \multicolumn{8}{|l|}{ Degosifier in proper operotion } \\
\hline \multicolumn{8}{|l|}{ Check cold trap reodings and servlce } \\
\hline Hyd tube samples "in" and "out" & & & & & & & \\
\hline
\end{tabular}

- To be performed during shurdowns 
CHECK IIST 8

DAILY ROUTINE INSTRUMENT CHECK LIST FOR ORR

Date

Instrument Technician

Shift Engineer

Power Level

Mw Charts on All Recorders

Check Standard Motors, Model H

Ink on AII Recorders

Check Batteries

\begin{tabular}{llllll}
\hline 1 & 2 & 3 & 4 & 5 & 6 \\
\hline
\end{tabular}

Magnet Amplifiers

Magnet Current

PA system

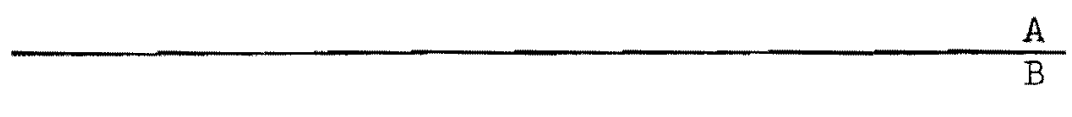

$\frac{\mathrm{A}}{\mathrm{B}}$

Gamma Chambers:

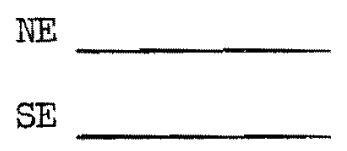

Sound Powered Phones

Log $\mathrm{N}$ Channel No. Percent Power

Sigma Amplifiers

No. I Safety No. 2 Safety

No. 3 Safety

Period

Heater Cathode Short

B + Unregulated

B + Regulated

$B+$ Current

Power

Condition of Trouble Monitors

Remarks 
CHECK LIST NO. 9

\section{ORR NORTH AND SOUTH FACILITIES}

Check List for Fllling and Draining.-Use with ORR Memo No. 59 (Rey. October, 1960)

\begin{tabular}{l} 
DATE \\
\hline Facility to be drained: \\
\hline \hline Main pump test blocks pulled \\
\hline Cut off facility cooling pump and valve shut
\end{tabular}

\section{FILLING THE FACILITIES}

Drain valves $N-2$ and N-3 closed

Droin volves S.706 and S-707 closed and locked

Grinnel valve 303 open

Fill valve $\mathrm{N}-1$ open

Fill volves $\$ 703$ and $\$-750$ open
Valve facility pump open and restart pump

Adjust south facility flow per MSR

Close vent volves

South facility flow gpm

North focility flow. gpm 


\section{CHTEK IITST 10 \\ Shim Rod Removal Check List}

In preparation for this operation, the necessary tools should be checked, balcony cleared and roped off, the procedure for rod transfers (1.3.3f) reviewed, etc. Shift engineers must closely supervise all parts of operation and initial at completion of operation.

1. Assure that all seat lights are showing, and that drives are near lower limit and drive unit is in locked position. Assure that magnet current is off. Seat switch actuating lever should be checked to assure that the shim rod is actually resting on the seat switch actuating rod.

2. Raise both hold-down arms by catching bail of are with a hook and tilting the arm east.

3. Remove the 4 fuel elements immediately (N, S, E, W) adjacent to the rod or rods to be moved. (This insures subcriticality.)

4. Position bridge above core, winch on bridge above rod, with cable directly over rod.

5. Unlock safety hook and lower into tank. Engage fuel hook in round locking pin eye.

6. Lower safety hook to rod and engage in rod handle. Lock hook by lifting safety pin eye slightly and rotating counterclockwise. Remove auxiliary fuel hook.

7. Raise drives enough so that 3 reclutching prongs clear 3 studs. Unlock rod by rotating locking handle. Leave drive unlocked.

8. Station a man to watch the count rate recorder. Raise rod slowly about 1 foot until sure rod is unlocked and free of the drive.

9. Clear bridge and poolside of unnecessary people. Make certain bridge can be moved.

10. Under radiation surveillance raise rod enough so that piston will clear top of tank. Move bridge west promptly, until rod can be lowered. Lower rod until radiation level tolerable. maximum reading $\mathrm{mr} / \mathrm{hr}$.

11. Identify rod.

12. Move rod to storage location and place there.

13. Unhook from rod and complete transfer memo.

A rod that is replaced in core must be locked and checked by the crew putting it in the core.

Date

Shift
Engineer

Rods Moved 


\section{Shim Rod Insertion Check List.}

In preparation for this operation, make sure the necessary tools are checked and available, the balcony cleared and roped off, the procedure for rod transfer (1.3.3f) reviewed, etc. Shift engineers must closely supervise a11. parts of operation and initial at completion of aperation.

1. Assure that the 4 fuel elements (N, S, E, W) immediately adjacent to the rod have been removed, the rod drive is unlocked and near lower limit, the hold-down arms are raised.

2. Place shim-rod winch on bridge, so cable will be directly over the future position of the rod.

3. (a) Applies to irradiated rods.

(1) Unlock safety hook and lower to rod. Engage in rod. Lock by lifting and turning latch eye counterclockwise.

(2) Under radiation survelllance raise the rod from storage location. Identify rod.

(3) Move bridge eastward. When near tank, raise rod under radiation surveillance enough to clear tank top. Immediately lower rod when above access flange until radiation subsides. Maximum reading $\mathrm{mr} / \mathrm{hr}$.

(b) Applies to unirradiated rods:

(1) Assure that rod is secure in the carrier.

(2) Engage locking hook of winch on rod and thread the special wire choker through the shim rod. Attach choker to crane hook and lift unit to vertical position. Remove carrier.

(3) Raise rod, move over pool, and lower into water until winch supports the rod.

(4) Remove the wire choker.

4. Position bridge so that rod is directly above the core position it will go in. Station a man to watch the count rate recorder while lowering rod.

5. Engage a fue 1 hook in the eye on the back of the hook to keep the rod from twisting while entering lower grid. The rod must hang vertically.

6. When the rod has entered the lower bearing properly, take the fuel hook off the safety hook. Continue lowering slowly until the rod is down and cable slacked. A seat light will show if drive was truly unlocked.

7. Send an operator to subpile room to lock the drive by rotating the locking handle. 


$$
-2-
$$

8. The locking of the rod must be checked by lifting up gently on the rod with the winch. A small upward movement will indicate the rod is free to move between seat and cross. If the upward movement is not stopped by the cross, the rod is free and must yet be locked.

9. An additional check can be made by raising the drive 5 inches and noting that the rod now can be raised some 5 inches also. Run drives back down, and assure that rod can no longer be raised.

10. Unlock safety hook from rod and remove.

Other fuel or rod movements may now be made.

A ROD THAT IS REPLACED IN CORE MUST BE LOCKED AND CHECKED BY THE CREW PUTTING IT IN THE CORE'.

Date

Shift
Engineer

Rods Moved and Checked 


\begin{tabular}{|c|c|}
\hline EXPEKIMENT & CHECKED BY \\
\hline AEACTOR \& ACILITY & DATE CHECKED \\
\hline
\end{tabular}

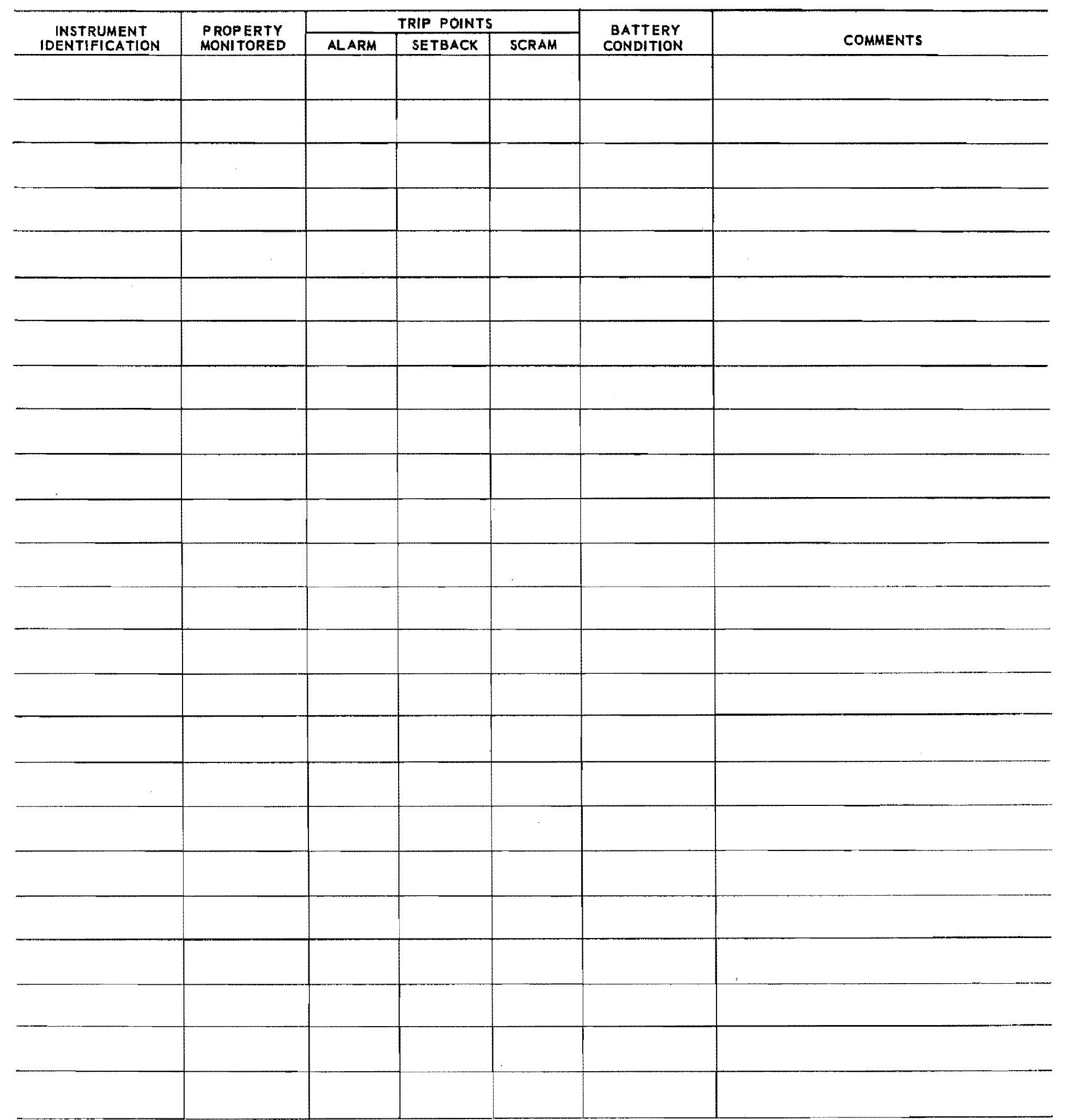


CHECK LIST 13

BEAM HOLE STATUS SHEET

Dak Ridge Research Reactor

\begin{tabular}{|c|c|c|c|c|c|c|c|c|c|c|c|c|c|}
\hline \multirow[b]{2}{*}{ Date } & \multirow[b]{2}{*}{ shift } & \multicolumn{2}{|c|}{$*_{\mathrm{HB}} \mathrm{-1}$} & \multicolumn{2}{|c|}{$* \mathrm{HB}-2$} & \multicolumn{2}{|c|}{$* \mathrm{HB}-3$} & \multicolumn{2}{|c|}{$*_{\mathrm{HB}-4}$} & \multicolumn{2}{|c|}{$* \mathrm{HB}-5$} & \multicolumn{2}{|c|}{$*_{\mathrm{HB}}-6$} \\
\hline & & Plug & Iiner & Plug & Liner & Plug & Liner & Plug & Liner & Plug & Liner & Plug & Line \\
\hline & & & & & & & & & & & & & \\
\hline & & & & & & & & & & & & & \\
\hline & & & & & & & & & & & & & \\
\hline & & & & & & & & & & & & & \\
\hline & & & & & & & & & & & & & \\
\hline & & & & & & & & & & & & & \\
\hline & & & & & & & & & & & & & \\
\hline & & & & & & & & & & & & & \\
\hline & & & & & & & & & & & & & \\
\hline & & & & & & & & & & & & & \\
\hline & & & & & & & & & & & & & \\
\hline & & & & & & & & & & & & & \\
\hline & & & & & & & & & & & & & \\
\hline & & & & & & & & & & & & & \\
\hline & & & & & & & & & & & & & \\
\hline & & & & & & & & & & & & & \\
\hline & & & & & & & & & & & & & \\
\hline & & & & & & & & & & & & & \\
\hline & & & & & & & & & & & & & \\
\hline
\end{tabular}

*Indicate status: Ex. $\mathrm{H}_{2} \mathrm{O}, \mathrm{He}, \mathrm{MT}$, etc。 
$\bullet$

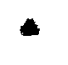

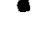


$-55-$

\section{DISTRIBUTION}

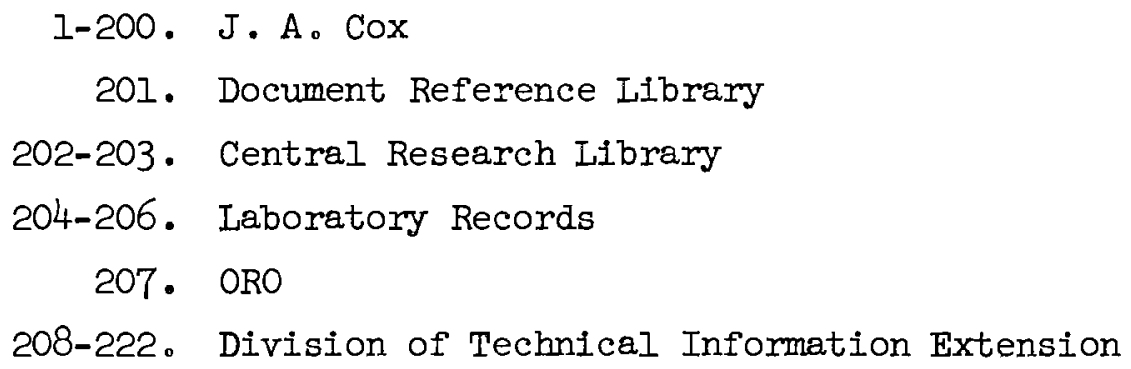


$y$ 